\title{
ANALISIS PERBANDINGAN KINERJA KEUANGAN DENGAN PENDEKATAN INCOME STATEMENT DAN VALUE ADDED STATEMENT PADA UNIT USAHA \\ SYARIAH
}

\author{
Istikanah \\ Universitas Negeri Malang \\ Bety Nur Achadiyah \\ Universitas Negeri Malang
}

\begin{abstract}
Abstrak: Teori-teori Akuntansi syariah berkembang seiring dengan perkembangan industri perbankan syariah dan lembaga keuangan syariah yang membutuhkan konsep akuntansi yang dianggap lebih sesuai dengan nilai Islam. Salah satu hasil rekonstruksi teori akuntansi syariah yakni adanya Laporan keuangan rekomendasi Value Added Statement yang dibuat dari konsep Sharia'ate Enterprise Theory yang menekankan pada distribusi nilai tambah kepada semua participant. Pada perkembangannya, Value added Statement digunakan untuk mengukur kinerja keuangan perusahaan pengganti Laporan Laba rugi (Value Added Statement). Penelitian ini bertujuan untuk mengetahui apakah terdapat perbedaan yang signifikan kinerja keuangan Unit Usaha Syariah (UUS) yang dianalisis dengan pendekatan Income statement dan value added statement. Penelitian ini merupakan replikasi dari penelitian sebelumnya yang bertujuan untuk menguji teori keagenan (agency theory) antara agent (manajer) dan prinsipal. Objek populasi yang digunakan dalam penelitian ini adalah Laporan Keuangan UUS Tahun 2010-2012 yang berjumlah 28 UUS. Teknik pengambilan sampel yang digunakan yakni Purposive sampling sehingga sampel yang dihasilkan adalah 16 UUS pada tahun 2010-2012 berjumlah 48 sampel. Uji hipotesis yang digunakan pada penelitian ini menggunakan uji beda berpasangan. Jika data berdistribusi normal, uji t beda dua sampel independen yang digunakan adalah t-test paired two samples yang merupakan uji statistik parametrik. Sedangkan jika data tidak berdistribusi normal, uji beda dua sampel independen yang digunakan adalah Wilcoxon Sign Rank Test yang merupakan uji statistik non parametrik. Hasil penelitian ini menunjukkan bahwa kinerja keuangan UUS dengan pendekatan Value Added Statement lebih tinggi dibandingkan dengan pendekatan Value Added Statement jika dilihat dari rasio Return On Asset (ROA), Return On Equity (ROE), Rasio Laba Bersih per Aktiva Produktif dan Rasio Net Profit Margin (NPM) pada tahun 2010-2012. Hal tersebut terjadi karena bagian pihak ketiga atas bagi hasil, gaji karyawan, zakat dan pajak tidak mengurangi pendapatan yang diperoleh tetapi merupakan bagian dari pendistribusian nilai tambah yang telah dihasilkan oleh UUS pada Value Added Statement. Saran yang dapat diberikan oleh peneliti adalah diterbitkan Value Added Statement sebagai tambahan laporan keuangan yang diterbitkan oleh UUS serta penambahan jumlah rasio kinerja keuangan yang digunakan, Disamping itu para para peneliti selanjutnya dapat melakukan penelitian berkaitan dengan penerapan Value Added Statement pada Unit Usaha Syariah.
\end{abstract}

Kata Kunci: Kinerja Keuangan, Unit Usaha Syariah, Syariah Enterprise Theory, Income Statement, Value Added Statement 


\section{JURNAL NOMINAL / VOLUME III NOMOR 2 / TAHUN 2014}

\section{PENDAHULUAN}

Islam merupakan agama yang mengatur berbagai aspek kehidupan termasuk kegiatan pencatatan transaksi ekonomi (akuntansi) yang berkaitan erat dengan prinsip muamalah. Teori-teori akuntansi dalam Islam dikenal dengan teori akuntansi syariah. Keberadaan Teori Akuntansi syariah berkembang melalui pengkajian oleh para intelektual muslim untuk memenuhi kebutuhan akan sistem akuntansi yang lebih syar'i pada entitas syariah.

Penilaian kinerja merupakan bagian dari kontrol terhadap aktivitas entitas syariah baik bank maupun lembaga keuangan bukan bank. Dalam usaha menilai kinerja pada lembaga keuangan maka dikenal dengan istilah penilaian kinerja keuangan. Penilaian kinerja keuangan bank syariah dapat dilakukan dengan menganalisis laporan keuangan yang diterbitkan.

Saat ini analisa kinerja keuangan bank syariah belum dapat dilakukan secara tepat. Praktik penilaian keuangan lembaga bisnis syariah pada umumnya hanya didasarkan pada neraca dan laporan laba rugi. Neraca dan laporan laba rugi yang digunakan yang masih mengadopsi filosofi, konsep serta teori konvensional. Hal tersebut dikarenakan keuangan bank syariah sebagaimana termuat dalam
Pernyataan Standar Akuntansi Keuangan Syariah (PSAK Syariah) No. 59 atau yang diperbaharui pada PSAK 101 hanya memuat sejumlah elemen laporan keuangan sebagaimana dalam laporan keuangan bank konvensional, meskipun laporan keuangan tersebut telah dilengkapi dengan beberapa laporan lainnya seperti laporan perubahan dana investasi terikat, laporan dana zakat, infaq, dan shodaqoh serta laporan qardul hasan (Laporan penggunaan dana kebajikan)

Kinerja keuangan lembaga keuangan syariah seharusnya diukur dengan menggunakan alat ukur kinerja yang lebih memperhatikan konsep keadilan. Shari'ate enterprise theory yang digagas oleh Baydoun dan willet (1994), dan Triwuyono (2001) dalam Mulawarman (2006: 114) menghasilkan sebuah Value Added Statement sebagai salah satu laporan keuangan yang menekankan distribusi yang dilakukan oleh perusahaan. Hal terpenting yang harus mendasari setiap penetapan shariate enterprise theory adalah Allah SWT sebagai pencipta dan pemilik tunggal dari seluruh sumberdaya yang ada di dunia ini. Dengan demikian kinerja perusahaan tidak hanya ditujukan kepada pemilik (stockholder) semata, namun juga kepada semua pihak yang terlibat baik secara langsung maupun tidak langsung terhadap aktivitas 


\section{JURNAL NOMINAL / VOLUME III NOMOR 2 / TAHUN 2014}

perusahaan.

Penelitian ini bertujuan untuk mengetahui Apakah terdapat perbedaan yang signifikan kinerja keuangan Unit Usaha Syariah (UUS) yang diwakili oleh Rasio ROA, ROE, LB/AP dan NPM jika dianalisis dengan pendekatan Laporan Laba Rugi (Income statement) dan Laporan Nilai Tambah (Value added statement).

\section{METODE PENELITIAN}

Penelitian ini merupakan penelitian kuantitatif dengan analisis data menggunakan statistik deskriptif dan inferensial. Sumber data penelitian ini ialah data sekunder berupa laporan keuangan UUS pada tahun 2010-2012. Populasi dalam penelitian ini ialah Unit usaha Syariah (UUS) yang dibentuk dari bank konvensional beragam, yakni 3 Unit Usaha Syariah Bank Persero, 7 Unit Usaha Syariah BUSN (Badan Usaha Swasta Nasional) Devisa, 1 Unit Usaha Syariah BUSN (Badan Usaha Swasta Nasional) Non Devisa, 15 Unit Usaha Syariah BPD, dan 1 Unit Usaha Syariah Bank Asing berjumlah 28 UUS. Setelah dilakukan pengambilan sampel dengan teknik purposive Sampling, terdapat 16 UUS yang menjadi sampel penelitian dengan periode tiga tahun, sehingga sampel yang digunakan sebanyak 48 laporan keuangan
UUS tahun 2010-2012.

Analisis data dilakukan untuk menguji hipotesis penelitian. Tahap pertama yang dilakukan ialah pengumpulan data. Setelah itu, langkah selanjutnya ialah pengolahan data yang dimulai dengan menghitung variabelvariabel yang digunakan. Untuk memperoleh data kinerja keuangan yang dihitung berdasarkan laporan laba rugi dapat diperoleh berdasarkan informasi pada laporan keuangan yang sudah diterbitkan oleh Unit Usaha Syariah, sedangkan untuk memperoleh data kinerja keuangan yang dihitung berdasarkan laporan nilai tambah maka peneliti akan membuat laporan nilai tambah berdasarkan data yang tersedia dalam laporan keuangan UUS sesuai dengan konsep Value Added Statement.

Setelah data kinerja keuangan berdasarkan laporan laba rugi dan nilai tambah diperoleh, selanjutnya dianalisa dengan menggunakan teknik statistik deskriptif dan inferensial untuk menjawab hipotesis penelitian. Untuk menguji apakah masingmasing variabel distribusi normal atau tidak, maka perlu dilakukan uji normalitas. Setelah diketahui hasil uji normalitas, jika data berdistribusi normal, uji t beda dua sampel independen yang digunakan adalah t- test paired two samples yang merupakan uji statistik 


\section{JURNAL NOMINAL / VOLUME III NOMOR 2 / TAHUN 2014}

parametrik dengan tingkat signiikansi satu arah $0.05 / 2$. Sedangkan jika data Data tidak berdistribusi normal, uji beda dua sampel independen yang digunakan adalah Wilcoxon Sign Rank Test yang merupakan uji statistik non parametrik dengan signifikansi 0.05/2.

\section{HASIL PENELITIAN DAN PEMBAHASAN}

Hasil Rekonstruksi Value Added Statement sebagai laporan pembanding Income Statement dalam menghitung kinerja keuangan (Chaerunnisa, 2010:16)

\begin{tabular}{ll}
\hline Sumber Nilai Tambah & \\
\hline Pendapatan Operasi Utama & $\mathrm{XXX}$ \\
\hline Pendapatan Sewa & $\mathrm{XXX}$ \\
\hline Pendapatan Bagi Hasil & $\mathrm{XXX}$ \\
\hline Pendapatan Operasi Lainnya & $\mathrm{XXX}$ \\
\hline Pendapatan Non Operasi & $\mathrm{XXX}$ \\
\hline Total Pendapatan & $\mathbf{X X X}$ \\
\hline Harga Pokok Input & $(\mathrm{XXX})$ \\
\hline Depresiasi & $(\mathrm{XXX})$ \\
\hline Revaluasi & $(\mathrm{XXX})$ \\
\hline Total Nilai Tambah & $\mathbf{X X X}$ \\
\hline Zakat & $\mathrm{XXX}$ \\
\hline Total Nilai Tambah bersih & $\mathbf{X X X}$ \\
\hline Distribusi nilai tambah & \\
\hline Nasabah bagi hasil & $\mathrm{XXX}$ \\
\hline Karyawan (gaji) & $\mathrm{XXX}$ \\
\hline Pajak & $\mathrm{XXX}$ \\
\hline
\end{tabular}

\begin{tabular}{ll}
\hline Deviden & $\mathrm{XXX}$ \\
\hline Laba ditahan & $\mathrm{XXX}$ \\
\hline Nilai Tambah Distribusi & $\mathbf{X X X}$ \\
\hline
\end{tabular}

\section{Uji Normalitas}

Hasil pengujian terhadap uji Kolmogorov Smirnov adalah sebagai berikut:

\section{Uji Normalitas ROA}

Dari hasil uji normalitas pada ROA UUS dapat diketahui bahwa Asymp Sig (2 Tailed) ROA Income Statement adalah 0.543. Untuk uji satu sisi, signifikansi adalah $\quad 0,543 / 2=0,272$ serta taraf signifikansi adalah $0.05 / 2=0.025$. Oleh karena 0,272>0,025, maka Ho diterima. Hal ini berarti distribusi data untuk variabel ROA Income Statement berdistribusi normal.

Sedangkan ROA untuk Value Added Statement 0.269>0.05. Untuk uji satu sisi, angka signifikansi adalah 0,269/2=0,135 serta taraf signifikansi adalah $0.05 / 2=0.025$. Oleh karena itu 0,135> 0,025 maka Ho diterima. Hal ini berarti distribusi data untuk variabel ROA Income Statement berdistribusi normal. Karena semua data berdistribusi normal sehingga uji statistik yang digunakan untuk membandingkan ROA pendekatan Income Statement dan Value Added Statement adalah adalah uji beda berpasangan statistik parametrik. Pada SPSS uji 


\section{JURNAL NOMINAL / VOLUME III NOMOR 2 / TAHUN 2014}

tersebut dapat dilakukan dengan menggunakan uji Paired T-test.

\section{Uji Normalitas ROE}

Dari hasil uji normalitas pada ROE UUS dapat diketahui bahwa Asymp Sig (2 Tailed) ROA Income Statement adalah 0,358. Untuk uji satu sisi, angka signifikansi adalah $0,358 / 2=0,179$ serta taraf signifikansi adalah $0.05 / 2=0.025$. Oleh karena 0,179> 0,025, maka Ho diterima. Hal ini berarti distribusi data untuk variabel ROA Income Statement berdistribusi normal.

Sedangkan ROE untuk Value Added Statement $0.269>0.05$. Untuk uji satu sisi, angka signifikansi adalah $0,000 / 2=0,000$ serta taraf signifikansi adalah $0.05 / 2=0.025$. Oleh karena $0,000<$ 0,025, maka Ho ditolak dan H1 diterima. Hal ini berarti distribusi data tidak normal. Dikarenakan ada data yang berdistribusi tidak normal, sehingga uji statistik yang digunakan untuk membandingkan ROA pendekatan Income Statement dan Value Added Statement adalah uji beda berpasangan statistik non parametrik. Pada SPSS uji tersebut dapat dilakukan dengan menggunakan uji Wilcoxon Signed Rank Test.

\section{Uji Normalitas LB/AP}

Dari hasil uji normalitas pada LB/AP

\section{Uji Normalitas NPM}

Dari hasil uji normalitas pada NPM UUS dapat diketahui bahwa Asymp Sig (2 Tailed) NPM dengan pendekatan Income Statement adalah 0.244. Untuk uji satu sisi, angka signifikansi adalah 


\section{JURNAL NOMINAL / VOLUME III NOMOR 2 / TAHUN 2014}

$0,244 / 2=0,122$ serta taraf signifikansi adalah $0.05 / 2=0.025$. Oleh karena $0,122>0,025$, maka Ho diterima. Hal ini berarti distribusi data untuk variabel ROA Income Statement berdistribusi normal.

Sedangkan NPM untuk Value Added Statement 0.002>0.05. Untuk uji satu sisi, angka signifikansi adalah $0,002 / 2=0,001$ serta taraf signifikansi adalah $0.05 / 2=0.025$. Oleh karena 0,002<0,025, maka Ho ditolak dan $\mathrm{H} 1$ diterima. Hal ini berarti distribusi data tidak normal. Dikarenakan ada data yang berdistribusi tidak normal, sehingga uji statistik yang digunakan untuk membandingkan ROA pendekatan Income Statement dan Value Added Statement adalah Wilcoxon Signed Rank Test. Dikarenakan ada data yang berdistribusi tidak normal Sehingga uji statistik yang digunakan untuk membandingkan NPM pendekatan Income Statement dan Value Added Statement adalah adalah uji beda berpasangan statistik non parametrik. Pada SPSS uji tersebut dapat dilakukan dengan menggunakan uji Wilcoxon signed Rank test.

\section{Uji Beda}

Dasar Pengambilan Keputusan pada hasil analisis ini adalah berdasarkan nilai signifikansi. Jika tingkat signifikansi $>0,05 / 2$, maka Ho diterima. Hal ini berarti tidak terdapat perbedaan Rasio ROA dengan menggunakan pendekatan Income Statement dan Value Added Statement. Begitupula sebaliknya jika tingkat signifikansi<0.05/2 maka H1 diterima

\section{Perbandingan Rasio ROA}

Berdasarkan hasil uji beda Paired t-test diketahui bahwa t hitung adalah $-12,884$ dengan sig 0,000. Oleh karena signifikansi $0,000<0,05 / 2$, maka Ho ditolak dan H1 diterima. Sehingga dapat disimpulkan bahwa Rasio Kinerja Keuangan pada UUS yang diwakili oleh ROA lebih tinggi dengan menggunakan pendekatan Value Added Statement dibandingkan dengan pendekatan Income Statement.

\section{Perbandingan Rasio ROE}

Berdasarkan hasil uji beda Wilcoxon Sign Rank Test dapat diketahui bahwa t hitung adalah $-12,884$ dengan sig 0,000 . Oleh karena signifikansi $0,000<$ 0,05/2, maka Ho ditolak dan H2 diterima. Sehingga dapat disimpulkan bahwa Rasio Kinerja Keuangan pada UUS yang diwakili oleh ROE lebih tinggi dengan menggunakan pendekatan Value Added Statement dibandingkan dengan pendekatan Income Statement.

\section{Perbandingan Rasio LB/AP}

Dari program SPSS Wilcoxon Sign Rank 19 


\section{JURNAL NOMINAL / VOLUME III NOMOR 2 / TAHUN 2014}

Test dapat diketahui bahwa asymp sign $0.000<0.05 / 2$. Dengan demikian hipotesis Ho ditolak dan $\mathrm{H} 3$ diterima. Dengan demikian berarti Rasio Kinerja Keuangan pada UUS yang diwakili oleh LB/AP lebih tinggi dengan menggunakan pendekatan Value Added Statement dibandingkan dengan pendekatan Income Statement.

\section{Perbandingan Rasio NPM}

Berdasarkan hasil uji beda Wilcoxon Sign Rank Test diketahui bahwa data hasil analisis pengujian hipotesis pada rasio NPM UUS sampel 0.000 maka dapat disimpulkan asymp sign $0.000<0.05 / 2$. Dengan demikian hipotesis Ho ditolak dan H4 diterima. Hal ini membuktikan Rasio Kinerja Keuangan pada UUS yang diwakili oleh NPM lebih tinggi dengan menggunakan pendekatan Value Added Statement dibandingkan dengan pendekatan Income Statement.

Perbedaan Return On Asset (ROA, ROE, LB/AP dan NPM) secara parsial dengan Pendekatan Income Statement dan Value Added Statement

Berdasarkan hasil pengujian hipotesis $\left(\mathrm{H}_{1}, \mathrm{H}_{2}, \mathrm{H}_{3}, \mathrm{H} 4\right)$ dengan menggunakan uji Paired sample T-test dan Wilcoxon signed Rank Test menunjukkan rasio ROA, ROE, LB/AP dan NPM secara parsial jika dihitung dengan pendekatan Value Added Statement lebih tinggi dibandingkan dengan pendekatan Income Statement pada UUS tahun 20102012.

Adanya perbedaan penerapan teori yang digunakan dalam Income Statement approach dan value added approach menyebabkan hasil analisis kinerja keuangan yang diwakili oleh ROA, ROE, LB/AP dan NPM menunjukkan hasil yang berbeda secara signifikan. Sehingga perolehan nilai tambah pengganti dengan menggunakan value added approach menunjukkan hasil yang lebih besar dibandingkan dengan laba yang diperoleh dengan menggunakan Income

Statement approach.

Besarnya jumlah pendapatan dikarenakan dalam Value Added Statement bagian pihak ketiga atas bagi hasil, gaji karyawan, zakat dan pajak tidak mengurangi pendapatan yang diperoleh tetapi merupakan bagian dari nilai tambah yang telah dihasilkan UUS. Bagian pihak ketiga atas bagi hasil masuk pada sisi distribusi dikarenakan bagian tersebut bagi hasil (prifit sharing) dari syirkah yang dilakukan oleh UUS dengan pihak-pihak ketiga. Dengan demikian pihak ketiga dianggap sebagai stakeholder yang harus dipenuhi haknya, bukan sebagai beban operasional bagi UUS. Pada Income 


\section{JURNAL NOMINAL / VOLUME III NOMOR 2 / TAHUN 2014}

Statement distribusi gaji karyawan diakui sebagai beban. Sedangkan pada pendekatan Value Added Statement karyawan dianggap sebagai salah satu pihak yang berhak mendapatkan distribusi nilai tambah yang dihasilkan perusahaan. Sehingga Gaji karyawan akan masuk pada sisi distribusi Value Added Statement. Besarnya distribusi karyawan dalam hal ini disesuaikan dengan akad yang dilakukan oleh perusahaan dengan karyawan dengan menjunjung tinggi nilai keadilan. Hal ini berarti hubungan antara karyawan dengan perusahaan harus menunjukkan proses pemenuhan hak dan kewajiban baik dari karyawan kepada perusahaan maupun sebaliknya.

Pertanggungjawaban secara vertikal pada UUS diwujudkan dalam bentuk pembayaran zakat. Meskipun pembayaran zakat ini ditujukan kepeda golongan yang berhak menerima zakat (mustahiq), namun memiliki esensi pertanggungjawaban secara vertikal kepada Tuhan. Zakat dalam Value Added Statement tidak menjadikan zakat sebagai pengurang pendapatan yang dapat mengurangi beban pajak perusahaan. Zakat merupakan kewajiban utama yang diperintahkan oleh Allah SWT sebagai konsekuensi atas rukun Islam dan sarana Islam dalam mengatur distribusi pendapatan. Sedangkan pajak merupakan kewajiban yang dibebankan oleh pemerintah dalam rangka menunjang pembangunan. Oleh karena itu salah satu kewajiban tidak akan mengurangi kewajiban yang lain sesuai dengan esensinya. Zakat dalam Value Added Statement masuk pada sisi distribusi Value Added. Sehingga secara keseluruhan seluruh beban pada Income Statement yang berkaitan dengan distribusi pendapatan kepada pihak-pihak yang berkepentingan dengan perusahaan akan masuk pada sisi distribusi Value Added pada Value Added Statement. Hal tersebut yang menyebabkan jumlah value added menjadi lebih besar dibandingkan dengan Laba/Rugi dalam Income Statement.

Secara kuantitatif semakin besar Rasio keuangan maka perusahaan dianggap dalam kondisi yang lebih baik. Besarnya ROA, ROE, LB/AP maupun NPM dengan menggunakan pendekatan Value Added Statement berarti bahwa rasio keuangan yang dinilai dari aspek distribusi menghasilkan rasio yang lebih besar. Sehingga hal ini akan mempengaruhi informasi yang akan ditangkap oleh para stakeholder maupun stockholder.

Value Added Statement dinilai memiliki motivasi disclosure yang sebenarnya masih bersandar pada principal egent model dari agency theory 


\section{JURNAL NOMINAL / VOLUME III NOMOR 2 / TAHUN 2014}

(Staden 2000 dalam Mulawarman, 2006: 149). Keberadaan Value Added Statement tersebut akan membantu Agen (manajer) untuk memenuhi kepentingan prinsipal sebagai salah satu pihak yang berhak atas pendistribusian Value Added yang dihasilkan perusahaan. Kewenangan yang diberikan oleh prinsipal digunakan para agen dalam hal ini manajemen perusahaan dengan melaporkan distribusi nilai tambah perusahaan kepada prinsipal secara keseluruhan

\section{SIMPULAN DAN SARAN}

\section{Kesimpulan}

Berdasarkan atas hasil penelitian dan pembahasan dengan uji beda Paired T-test dan Wilcoxon signed Rank test yang bertujuan untuk menganalisis perbandingan kinerja keuangan UUS menggunakan pendekatan Income Statement dan Value added statement maka dapat ditarik kesimpulan rasio ROA, ROE, LB/AP dan NPM secara parsial pada tahun 2010-2012 dengan menggunakan pendekatan Value Added Statement lebih tinggi dibanding menggunakan pendekatan Income Statement. Hal tersebut terjadi karena bagian pihak ketiga atas bagi hasil, gaji karyawan, zakat dan pajak tidak mengurangi pendapatan yang diperoleh tetapi merupakan bagian dari pendistribusian nilai tambah yang telah dihasilkan oleh UUS.

\section{Keterbatasan Penelitian}

Penelitian ini memiliki keterbatasan yang perlu dipertimbangkan dalam memberikan penilaian atas hasil penelitian yakni, Value Added Statement merupakan laporan rekomendasi yang masih belum memiliki standar baku, jadi antara peneliti satu dengan yang lain berkemungkinan untuk memiliki pandangan yang berbeda terkait perhitungannya.

\section{Saran}

Berdasarkan kesimpulan dan keterbatasan penelitian diatas saran Adanya Value Added Statement memberikan informasi yang berkaitan dengan pendistribusian bagi hasil yang diperoleh oleh UUS. Oleh sebab itu, ada baiknya UUS di Indonesia bersedia menerbitkan Value Added Statement sebagai tambahan laporan keuanganyang diterbitkan. Penelitian ini hanya menggunakan 4 rasio dalam mengukur kinerja perbankan, maka sebaiknya peneliti yang akan datang menggunakan lebih banyak rasio sehingga lebih mencerminkan kinerja keuangan secara umum. Belum adanya standart baku Value Added Statement sehingga para peneliti selanjutnya dapat melakukan penelitian 


\section{JURNAL NOMINAL / VOLUME III NOMOR 2 / TAHUN 2014}

lebih mendalam berkaitan dengan penerapan Value Added Statement pada sebuah Perusahaan atau Lembaga keuangan.

\section{DAFTAR PUSTAKA}

Antonio, Syafi'i. 2001. Bank Syariah dari Teori ke Praktik. Jakarta: Gema Insani Press.

Ascarya dan Yumanita Diana.2005. Bank Syariah: Gambaran Umum. Jakarta: Pusat Pendidikan Dan Studi Kebanksentralan (PPSK).

Brigham, Eugene F. dan Houston, Joel F. 2012. Dasar-dasar Manajemen Keuangan Edisi II. Jakarta: Salemba Empat.

Chaerunnisa, Nadya; Hery Susanto. 2011. Analisis Perbandingan Kinerja Keuangan Natara Pendekatan Laporan Laba Rugi Dengan Shari'ate Value Added Statement Pada PT Bank Syariah Mandiri. Jurnal Proceeding Vol. 4. Oktober 2011 Pesat (Psikologi, Ekonomi, Sastra, Arsitektur Dan Sipil) Universitas Gunadarma.

Damastuti, Isnaini Endah.2010. Analisis Perbandingan Kinerja Keuangan Bank Syariah Dengan Menggunakan Income Statement Approach Dan Value Added Approach (Studi Kasus Bank
Muamalat Indonesia Cabang

Semarang). Skripsi Tidak

Diterbitkan.

Damyanti, Ana. 2012. Analisis Perrbandingan Kinerja Keuangan Bank Syariah Dengan Metode Income Statement Approach Dan Value Added Approach Dan Pengaruhnya Terhadap Pertumbuhan Bank (Studi Kasus Pada Bank Muamalat Indonesia Cabang Tasikmalaya). Skripsi Tidak Diterbitkan. Universitas Siliwangi.

Hafida, andi safitri (2012). Implementasi Shariah Enterprise Theory Melalui Value Added Statement Untuk Menilai Tanggung Jawab Perbankan Syariah Kepada Stakeholders Universitas Hasanudin.

Hanafi, Mamduh M. Dan Halim, Abdul. 2003. Analisis Laporan Keuangan. Yogyakarta: Unit Penerbit dan Percetakan AMP-YKPN.

Harahap, Sofyan Syafri.2001. Мепијu Perumusan Teori Akuntansi Islam. Jakarta: Pustaka Quantum.

Karim, Helmi. 1993. Fiqh Muamalah. Jakarta: PT Raja Grafindo Persada. Karim, Adimarwan. 2010. Bank Islam : Analisis Fiqih Dan Keuangan. Jakarta: PT Raja Grafindo Persada. 


\section{JURNAL NOMINAL / VOLUME III NOMOR 2 / TAHUN 2014}

Muhammad.2005. Pengantar Akuntansi

Syariah. Jakarta: Salemba Empat.

Muhammad. 2002. Manajemen Bank Sfac

Syariah. Yogyakarta.

Mulawarman, Aji Dedi.2006. Menyibak

Akuntansi Syariah. Yogyakarta:

Kreasi Wacana.

2006. Rekonstruksi

Teknologi Integralistik Akuntansi

Syari"ah: Shari"ate Value Added

Statement. Simposium Nasional

Akuntansi 9 Padang. . 2009. Akuntansi Syariah:

Teori Konsep dan Laporan

Keuangan. Jakarta: E Publising.

Nucleusita, Radias. 2012. Analisis

Perbandingan Kinerja Keuangan

Bank Umum Syariah Dengan

Pendekatan Laporan Laba Rugi

Dan Laporan Nilai Tambah Pada

Bank Umum Syariah. Skripsi,

Jurusan Akuntansi, Universitas

Negeri Malang.

Pedoman Penulisan Karya Ilmiah

Universitas Negeri Malang 2007

Psak

101.2013.

Abufadilah.Files.Wordpress.Com/2

011/07/Psak-101.Pdf. (diakses 22 agustus 2013)

Psak

59.2013.

Abufadilah.Files.Wordpress.Com/2
011/07/Psak-59.Pdf (diakses 22

agustus 2013)

no1.

2011.

Www.Becker.Com/Accounting/.../

$2011 \% 20$ Financial\%201\%20

Update.Pdf (diakses 6 September 2013).

Statistik Perbankan Indonesia.2013.www.

bi.go.id (diakses 2 September 2013) Sugiyono. 2004. Metode Penelitian Bisnis. Bandung: CV Alfabeta.

Surat Keputusan Direksi Bank Indonesia No. 31/147/Kep/Dir Tanggal 12 November 1998 Tentang Kualitas Aktiva Produktif.

Triyuwono, Iwan.2009. Perspektif, Metodologi Dan Teori Akuntansi Syariah.Jakarta: Rajawali Pers.

Triyuwono, Iwan Dan As'udi, Muhammad.2011.Akuntansi

Syariah. Jakarta: Salemba Empat Undang-Undang Nomor 10 Tahun 1998

Undang-Undang Nomor 21 Tahun 2008 Pasal 1

Yaya Rizal. 2009.Akuntansi Perbankan Syariah Teori Dan Praktik Kontemporer. Jakarta: Salemba Empat. 